\title{
A Nonviral DNA Delivery System Based on Surface Modified Silica-Nanoparticles Can Efficiently Transfect Cells in Vitro
}

\author{
Carsten Kneuer, ${ }^{\dagger}$ Mohammad Sameti, ${ }^{\dagger, \ddagger}$ Udo Bakowsky, ${ }^{\S}$ Thomas Schiestel, ${ }^{\ddagger}$ Hermann Schirra, ${ }^{\ddagger}$ \\ Helmut Schmidt, ${ }^{\ddagger}$ and Claus-Michael Lehr*,† \\ Department of Biopharmaceutics and Pharmaceutical Technology, Saarland University, \\ 66041 Saarbrücken, Germany, Institute for New Materials gemGmbH, Im Stadtwald, 66123 Saarbrücken, \\ Germany, and Department of Physiological Chemistry, University of Groningen, Groningen, The Netherlands. \\ Received J une 1, 2000; Revised Manuscript Received September 18, 2000
}

\begin{abstract}
Diverse polycationic polymers have been used as nonviral transfection agents. Here we report the ability of colloidal silica particles with covalently attached cationic surface modifications to transfect plasmid DNA in vitro and make an attempt to describe the structure of the resulting transfection complexes. In anal ogy to the terms lipoplex and polyplex, we propose to describe the nanoparticleDNA complexes by the term "nanoplex". Three batches, Si 10E, Si100E, and Si26H, sized between 10 and $100 \mathrm{~nm}$ and with $\zeta$ potentials ranging from +7 to $+31 \mathrm{mV}$ at $\mathrm{pH} 7.4$ were evaluated. The galactosidase expression plasmid DNA pCMV $\beta$ was i mmobilized on the particle surface and efficiently transfected Cos-1 cells. The transfection activity was accompanied by very low cytotoxicity, with $L_{50}$ values in the milligrams per milliliter range. The most active batch, Si26H, was produced by modification of commercially available silica particles with $\mathrm{N}$-(6-aminohexyl)-3-aminopropyltrimethoxysilane, yielding spherical nanoparticles with a mean diameter of $26 \mathrm{~nm}$ and a $\xi$ potential of +31 $\mathrm{mV}$ at $\mathrm{pH}$ 7.4. Complexes of Si26H and $\mathrm{pCMV} \beta$ plasmid DNA formed at w/w ratios of 10 were most effective in promoting transfection of Cos-1 cells in the absence of serum. At this ratio, $>90 \%$ of the DNA was associated with the particles, yiel ding nanoplexes with a net negative surface charge. When the transfection medium was supplemented with $10 \%$ serum, maximum gene expression was observed at a w/w ratio of 30, at which the resulting particle-DNA complexes possessed a positive surface charge. Transfection was strongly increased in the presence of $100 \mu \mathrm{M}$ chloroquine in the incubation medium and reached approximately $30 \%$ of the efficiency of a $60 \mathrm{kDa}$ polyethylenimine. In contrast to polyethylenimine, no toxicity was observed at the concentrations required. Atomic force microscopy of Si26H-DNA complexes revealed a spaghetti-meatball-like structure. The surface of complexes prepared at a w/w ratio of 30 was dominated by particles half-spheres. Complex sizes correlated well with those determined previously by dynamic light scattering.
\end{abstract}

\section{INTRODUCTION}

The past decade has witnessed the arrival of a range of new synthetic transfection agents, including cationic peptides, dendrimers, polyethylenimine, and novel lipids (1-5). The efficiency of nonviral transfection systems has improved several orders of magnitude. However, this is not due to the discovery of new transfection reagents per se, but also a product of the grown understanding of the biological processes that take place during transfection and the rational manipulation of these. Milestones include the concept of receptor targeting (6) and endosomal escape (chloroquine, endosomolytic peptides and viruses, proton sponges) (3, 7-9). Currently, research groups are seeking ways to facilitate the nuclear transfer of transfected DNA after it has entered the cytoplasm $(10,11)$ or to circumvent this problem by cytoplasmic gene expression (12). Exhaustive reviews on these topics have been published recently (13-15). Along with the more detailed understanding of transfection, the most

$*$ To whom correspondence should be addressed. Phone: +49 (0)681 302 2039. Fax: +49 (0)681 302 4677. E-mail: lehr@rz.unisb.de.

† Saarland University.

₹ Institute for New Materials gemGmbH, Im Stadtwald.

$\S$ University of Groningen. advanced transfections agents are getting increasingly complex and might already be termed transfection "systems". These will carry a number of functional components that can be more or less integrated: (1) a plasmid or other suitable form of DNA, (2) a DNA carrier, (3) one or more receptor ligand, (4) an endosomolytic factor, (5) a nuclear localization signal, (6) a biocompatible shell and structures to link these functions. With the rising number of necessary components it is becoming increasingly difficult to tightly control the synthesis of such complexes. Wagner and colleagues have successfully employed a system that, in its most complex form, consists of DNA, polylysine or polyethylenimine, a streptavidin-biotin linker, inactivated adenovirus, and transferrin (16).

In an attempt to provide alternative DNA carriers for the assembly of such gene transfer systems, we have evaluated the potential of cationically modified silica nanoparticles as a transfection reagent. The ability of these particles to bind and to protect plasmid DNA was shown recently (17).

Many polycationic transfection agents are limited in their in vitro transfection efficiency by a pronounced reduction in cell viability. Frequently, the peak in transgene expression is paralleled by the onset of cytotoxicity $(2,3,18,19)$. Although some mechanistic studies have 
shown the immobilization of membrane patches (20), lipid redistribution (21), or the thermodynamic stabilization of lipid bilayers by polycations (22), the processes that mediate the in vitro toxicity of polycations such as polylysine or polyethyleneimine is not understood. Recent approaches to reduce the toxicity of polymer-based transfection systems include the optimization of formulation parameters (19) or the modification of the polymer side chains by glycolylation (23). Attention was therefore also paid to the effect of the newly synthesized DNA delivery vehicles on the viability of the exposed cell cultures.

\section{EXPERIMENTAL PROCEDURES}

Synthesis of Cationic Silica Nanoparticles. Silica particles surface modified with aminoalkylsilanes were produced as reported previously (17). Briefly, batches Si10E and Si26H were synthesized by modification of commercial ly available silica particles (IPAST, NISSAN Chemical Industries, Tokio, J apan) with $\mathrm{N}$-(2-aminoethyl)-3-aminopropyltrimethoxysilane (AEAPS) or N-(6aminohexyl)-3-aminopropyltrimethoxysilane (AHAPS). Twenty grams of particle suspension (corresponding to $6 \mathrm{~g}$ of particle dry weight), $20 \mathrm{~g}$ of water, and $12 \mathrm{~mL}$ of concentrated acetic acid were stirred for $16 \mathrm{~h}$ at $80^{\circ} \mathrm{C}$ with $7.2 \mathrm{~g}$ of AEAPS (Si10E) or $6 \mathrm{~g}$ of AHAPS $(\mathrm{Si} 26 \mathrm{H})$. The product was chilled, mixed with $25 \mathrm{~mL}$ of ethylene glycol, rotated for $2 \mathrm{~h}$ under vacuum at $50{ }^{\circ} \mathrm{C}$, and dialyzed five times for $24 \mathrm{~h}$ against $20 \mathrm{~L}$ of deionized water. For the synthesis of Si 100E, silica particles were generated by the method of Stoeber (31) and subse quently modified with one weight equival ent of AEAPS. A mixture of $8 \mathrm{~g}$ of triethoxysilane (TEOS) and $13 \mathrm{~g}$ of ammonium in $250 \mathrm{~mL}$ of ethanol was subjected to a controlled hydrolysis and condensation reaction for $16 \mathrm{~h}$ at room temperature. The particles were collected by centrifugation, washed five times and modified with 4.36 $g$ of AEAPS as described above. AEAPS, AHAPS, and TEOS were purchased from ABCR (Karlsruhe, Germany).

Degree of Modification of Si26H. The relative carbon content of unmodified and modified silica particle was measured on a $\mathrm{C} / \mathrm{H}$-analyzer, RC-412 (Leco, St. J oseph), using 100-200 mg of particle dry weight. The increase in carbon content was then related to the molecular weight of the hydrolyzed modificator (AHAPS) of $209 \mathrm{~g} / \mathrm{mol}$. This al lowed the calculation of the degree of cationic modification of the base particle in moles of nitrogen per gram of particle dry weight.

Light Scattering Measurements of $\zeta$ Potential and Particle Size. $\zeta$ Potential titration curves were obtained using a Malvern Zetasizer 4 (Malvern, U.K.). The instrument was calibrated routinely with a $-55 \mathrm{mV}$ standard. Particle size was determined by photon correlation spectroscopy on a ALV 5000 (Laser Vertriebsgesellschaft $\mathrm{mbH}$, Langen, Germany) at a scattering angle of $90^{\circ}$ (sampling time $300 \mathrm{~s}$ ).

Atomic Force Microscopy (AFM). Si26H-DNA complexes were mixed at a $\mathrm{w} / \mathrm{w}$ ratio of 30 in distilled water, adsorbed to the surface of silicium wafers and the wet surface was examined by atomic force microscopy on a Nanoscope III a in tapping mode using a $\mathrm{Si}_{3} \mathrm{~N}_{4}$ cantilever with a spring constant of $34 \mathrm{~N} / \mathrm{m}$. Scanning was performed at a scan speed of $2 \mathrm{~Hz}$ with a resolution of $512 \times 512$ pixels. The tip loading force was minimized to avoid structural changes to the sample.

Ethidium Bromide Exclusion Test. For the measurement of ethidium bromide exclusion, DNA was diluted in $50 \mathrm{mM}$ Hepes (pH 7.4) to yield a final
Table 1. Physicochemical Characteristics of Si10E, Si 100E, and Si26H

\begin{tabular}{|c|c|c|c|c|c|}
\hline particle & $\begin{array}{c}\text { size }(\mathrm{nm}) \\
\text { (range) }\end{array}$ & $\operatorname{IEP}(\mathrm{pH})$ & $\begin{array}{c}\xi_{\mathrm{pH} 7.4}(\mathrm{mV}) \\
\left(\xi_{\max } \text {, fitted) }\right.\end{array}$ & $\begin{array}{l}\mathrm{mol} \text { of } \mathrm{N} / \\
\mathrm{g} \text { of SiNP }\end{array}$ & $\begin{array}{l}\text { spacer in } \\
\text { amino- } \\
\text { alkylsilane }\end{array}$ \\
\hline Si10E & $\begin{array}{l}10 \\
(8-12)\end{array}$ & 8.1 & $\begin{array}{l}+17 \\
(+44)\end{array}$ & nd & ethyl \\
\hline Si100E & $\begin{array}{l}145 \\
(70-220)\end{array}$ & 7.7 & $\begin{array}{l}+7 \\
(+56)\end{array}$ & nd & ethyl \\
\hline $\mathrm{Si} 26 \mathrm{H}$ & $\begin{array}{l}26 \\
(16-50)\end{array}$ & 8.6 & $\begin{array}{l}+31 \\
(+57)\end{array}$ & 0.00048 & hexyl \\
\hline
\end{tabular}

concentration of $10 \mu \mathrm{g} / \mathrm{mL}$, mixed with the desired amount of particle suspension or polymer solution and incubated for $3 \mathrm{~min}$. The final reaction volume was $2 \mathrm{~mL}$ in all cases. One milliliter of ethidium bromide (800 ng/ $\mathrm{mL}$ ), or water for the detection of background fluorescence, was added to onehalf of the sample and the fluorescence was measured at $\lambda_{\mathrm{ex}}=366 \mathrm{~nm}$ and $\lambda_{\mathrm{em}}=$ $590 \mathrm{~nm}$ in a F-2000 fluorescence spectrophotometer (HITACHI, J apan).

Agarosegel Electrophoresis. Nanoparticle-DNA complexes were prepared by mixing in $200 \mu \mathrm{L}$ of $25 \mathrm{mM}$ Hepes (pH 7.4) at a plasmid concentration of $20 \mu \mathrm{g} / \mathrm{mL}$ and electrophoresed on agarose gel $(0.7 \%$, ethidium bromide included for visualization) for $2 \mathrm{~h}$ at $70 \mathrm{~V}$. I mages were taken using a UV transilluminator and a Geldoc2000 gel documentation system (Bio-Rad, Munich, Germany). Band integration and background correction was performed using Molecular Analyst, version 1.1 software (Bio-Rad).

Cosedimentation Analysis. To measure the removal of DNA from the solution, nanoparticle-DNA complexes were prepared as described above and subjected to centrifugation at $21.000 \mathrm{~g}$ for $15 \mathrm{~min}$ at room temperature. The concentration of soluble DNA in the supernatant was determined with Hoechst 33258 dye (24).

Cell Culture. Cos-1 cells were obtained from DSMZ (Braunschweig, Germany) and maintained in Dulbecco's modified eagle's medium (DMEM), supplemented with $10 \%$ fetal calf serum (Gibco BRL). Cells were incubated at $37{ }^{\circ} \mathrm{C}$ with $5 \% \mathrm{CO}_{2}$ in air and subcultured every three to four days using trypsin/EDTA.

Transfections and Cytotoxicity Assay. For transfection, Cos-1 cells were plated in 96-well plates or 16well chamber slides (Greiner) at a density of 10.000 cells/ well and allowed to adhere overnight. Nanopartide-DNA complexes were prepared by adding the desired amount of particle suspension to $20 \mu \mathrm{g} / \mathrm{mL}$ (final concentration) plasmid DNA in water. After 15 min equillibration at room temperature, the complexes were diluted with one volume of 2xDMEM with or without $20 \%$ FCS and 200 $\mu \mathrm{M}$ chloroquine. The semiconfluent monolayers were washed once with PBS and incubated with $100 \mu \mathrm{L}$ of the test suspension for $4 \mathrm{~h}$ at $37{ }^{\circ} \mathrm{C}$ with $5 \% \mathrm{CO}_{2}$ in air. The cells were washed once with PBS and incubated for a further $48 \mathrm{~h}$ in DMEM + 10\% FCS. Cytotoxicity of NP and NP-DNA complexes was determined in a separate set of experiments using the WST-1 assay (Boehringer Mannheim, Germany) according to the manufacturer's instructions. All assays were performed in six replicates.

$\boldsymbol{\beta}$-Galactosidase Detection. To assay the average cellular expression of $\beta$-galactosidase, cells were washed once with PBS and lysed with $100 \mu \mathrm{L}$ of $0.2 \%$ Triton $\mathrm{X}-100$ (SI GMA) in PBS per well for 30 min at $4{ }^{\circ} \mathrm{C}$. Fifty microliters of lysate was mixed with $50 \mu \mathrm{L}$ of fresh reaction solution ( $5 \mathrm{mM}$ 4-methyl-umbeliferryl- $\beta$-D-galactoside, $100 \mathrm{mM}$ D-galactose, and $2 \mathrm{mM} \mathrm{M} \mathrm{gCl}{ }_{2}$ in PBS, $\mathrm{pH}$ 7.4) and incubated for $4 \mathrm{~h}$ at $37^{\circ} \mathrm{C}$. The reaction was stopped by the addition of $100 \mu \mathrm{L} 0.2 \mathrm{M}$ glycine- $\mathrm{NaOH}$ 
$(\mathrm{pH} 10.3)$ and the fluorescence $\left(\lambda_{\mathrm{ex}}=360 \mathrm{~nm}\right.$ and $\lambda_{\mathrm{em}}=$ $460 \mathrm{~nm}$ ) was measured in a Cytofluor II microplate fluorescence reader (Perseptive Biosystems, Bedford, MA). Purified recombinant $\beta$-galactosidase (SIGMA, Deisenhofen, Germany) was used as standard. Total protein content was determined from $25 \mu \mathrm{L}$ of lysate using the BCA assay (Pierce).

For X-Gal staining, cells were fixed with $4 \%$ paraformaldehyde for $5 \mathrm{~min}$ at room temperature and stained with $1 \mathrm{mg} / \mathrm{mL}$ X-Gal (peqlab, Erlangen, Germany) in PBS for $4 \mathrm{~h}$ or overnight.

DNA. The $\beta$-galactosidase expression plasmid $\mathrm{pCMV} \beta$ was purchased from ATCC (Manassas, VA) and transformed into Escherichia coli DH $5 \alpha$. A Gigaprep from 2500 $\mathrm{mL}$ of overnight culture was performed according to the manufacturers instructions (QI AGEN, Hilden, Germany). The DNA was precipitated in $70 \%$ ethanol and reconstituted in water to $1 \mathrm{mg} / \mathrm{ml}$.

Other Chemicals. Polyethylenimine with an average molecular weight of $60 \mathrm{kDa}$ according to the manufacturer's information was purchased from SIGMA (Deisenhofen, Germany).

\section{RESULTS}

Transfection Activity of NP-DNA Complexes. The ability of Si10E, Si100E, and Si26H to transfect the pCMV $\beta$ reporter gene plasmid at a fixed concentration of $10 \mu \mathrm{g} / \mathrm{mL}$ into Cos-1 cells was tested in serum-free and serum-containing medium in the absence and presence of $100 \mu \mathrm{M}$ chloroquine. As shown in Figure 1A, all tested SiNPs were able to promote transfection. The efficiency was influenced by a number of parameters including the w/w ratio of SiNP:DNA, presence of FCS and presence of chloroquine. The pattern of transfection activity in response to the variables was similar for all nanoparticles.

Presence of $100 \mu \mathrm{M}$ chloroquine in the transfection medium generally enhanced transfection by all nanoparticles, although there was substantial variation in magnitude. The effect of chloroquine was especially pronounced in the presence of serum, where it could enhance transfection by more than 10-fold for all nanoparticles.

There was also an optimum for the w/w ratio of particle to DNA. In the absence of serum but presence of chloroquine, this was 20,10, and 10 for Si10E, Si 100E, and $\mathrm{Si} 26 \mathrm{H}$, respectively. Above this optimum, a slight but constant decrease in galactosidase activity was observed. This, however, was not accompanied by a reduction in cellular protein content (not shown).

Addition of serum did not affect or improve the efficiency of transfection by all SiNPs. While this effect was relatively small or in some cases only marginal when Si10E or Si100E were used, the improvement of transfection by $\mathrm{Si} 26 \mathrm{H}$ complexes prepared at a ratio of 30 was more than 10-fold. The addition of chloroquine and serum in combination improved galactosidase expression by 2 orders of magnitude, reaching approximately $30 \%$ of the levels achieved with polyethylenimine-DNA polyplexes prepared at a N/P ratio of $7.5(\mathrm{w} / \mathrm{w}=1)$. At this ratio, pE I-DNA polyplexes showed the highest level of galactosidase expression in Cos-1 cells in our lab. However, maximum transfection activity coincided with $50 \%$ reduction in cellular protein levels when pEI was used as transfection agent.

Figure 1 , panels $B$ and $C$, show the influence of the SiNP to DNA ratio on the resulting galactosidase expression levels in more detail. Low but significant enzyme levels were detectable at w/w ratios of 3 . In both cases,
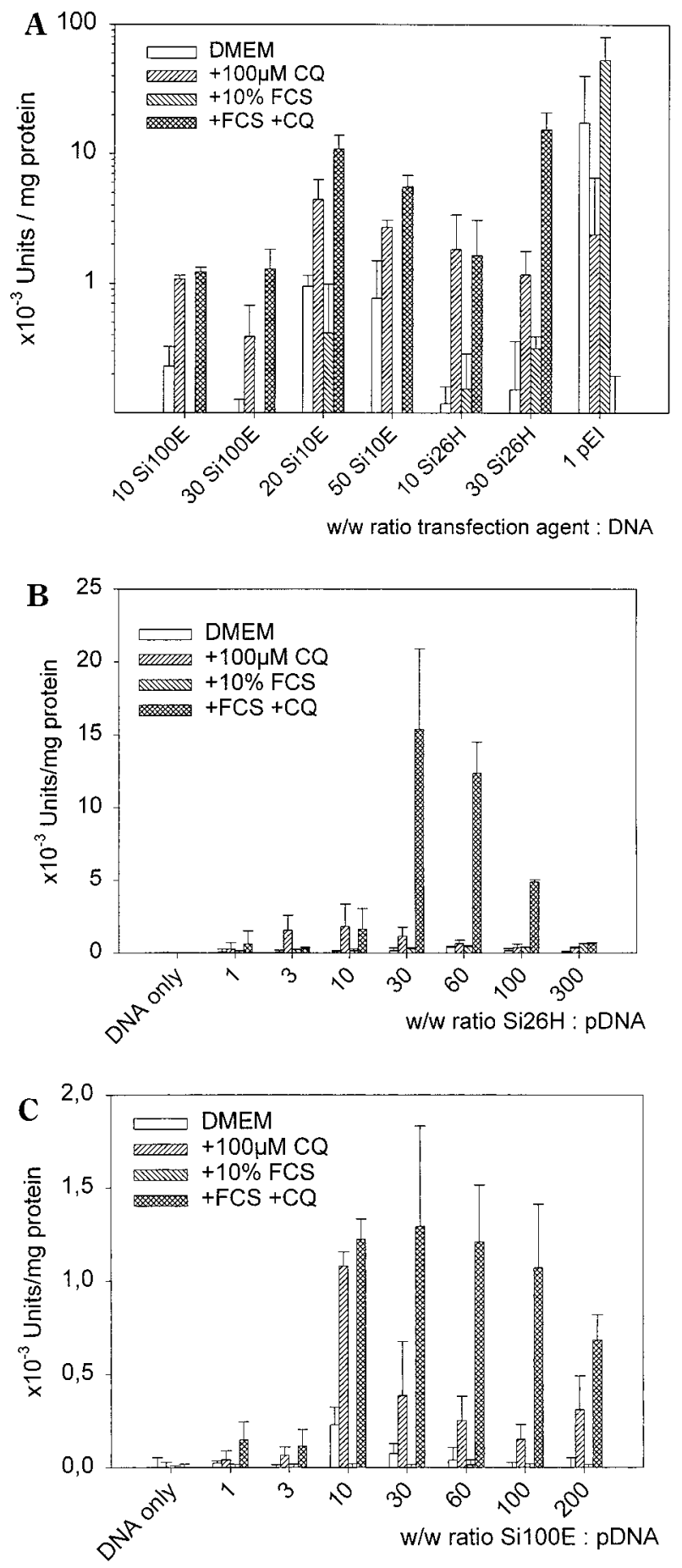

Figure 1. Transfection with pEI, Si10E, Si100E, and Si26H. Semiconfluent Cos-1 cells were incubated with transfection complexes as described in the Materials and Methods. Expression of $\beta$-galactosidase was determined using the fluorogenic substrate 4-methyl-umbelliferryl- $\beta$-D-galactoside. A total of $10^{-3}$ enzyme units corresponds to approximately 2 ng of enzyme, and the detection limit was $10 \mathrm{pg}$ of enzyme/well.

transfection in the absence of serum peaked at a ratio of 10 . When more particles were added, the activity slowly declined. Supplementation of the transfection medium with $10 \%$ of fetal calf serum shifted the curve to higher SiNP:DNA ratios with a maximum at a w/w ratio of 30. Gene expression in experiments performed without the addition of $100 \mu \mathrm{M}$ chloroquine was at a 2-10-fold lower level but paralleled this course.

Incubation with naked DNA did not result in measurable levels of galactosidase expression in this experimen- 
Table 2. In vitro Cytotoxicity of All Transfection Agents Used $^{\mathrm{a}}$

\begin{tabular}{ccc}
\hline & \multicolumn{2}{c}{ LD $_{50}$ (Cos-1 cells) } \\
\cline { 2 - 3 } transfection agent & DMEM & DMEM $+10 \% \mathrm{FCS}$ \\
\hline $\mathrm{pEI}$ & $20 \mu \mathrm{g} / \mathrm{mL}$ & $40 \mu \mathrm{g} / \mathrm{mL}$ \\
Si $10 \mathrm{E}$ & $>1 \mathrm{mg} / \mathrm{mL}$ & $>1 \mathrm{mg} / \mathrm{mL}$ \\
$\mathrm{Si} 100 \mathrm{E}$ & $>1 \mathrm{mg} / \mathrm{mL}$ & $>1 \mathrm{mg} / \mathrm{mL}$ \\
$\mathrm{Si} 26 \mathrm{H}$ & $2.5 \mathrm{mg} / \mathrm{mL}$ & $>6 \mathrm{mg} / \mathrm{mL}$ \\
$\mathrm{pCMV} \beta$ & $>1 \mathrm{mg} / \mathrm{mL}$ & $>1 \mathrm{mg} / \mathrm{mL}$ \\
chloroquine & $7.5 \mathrm{mM}$ & $9.5 \mathrm{mM}$
\end{tabular}

a Semiconfluent Cos-1 cells grown on 96-well plates were incubated for $4 \mathrm{~h}$ with increasing concentrations of the transfection agent in DMEM or DMEM $+10 \% \mathrm{fcs}$, supplied with fresh medium and assayed for viability (WST-1 assay) after a further $48 \mathrm{~h}$ of growth in DMEM supplemented with $10 \%$ fcs.

tal setup. The transfection activity of SiNP-DNA complexes based on 10 and 30 weight equivalents of Si100E and $\mathrm{Si} 26 \mathrm{H}$ was confirmed by histochemical staining with $\mathrm{X}-\mathrm{Gal}$ (not shown).

In Vitro Cytotoxicity of the Transfection Reagents. All transfection reagents were characterized with regard to their effect on the viability of Cos-1 cell monolayers under the same conditions as used for transfection experiments. The $L D_{50}$ values are summarized in Table 2. Only polyethylenimine significantly reduced the viability at concentrations required for efficient transfection. All nanoparticles tested displayed a 50\% lethal concentration well above $1 \mathrm{mg} / \mathrm{ml}$. Panels A and B of Figure 2 compare the cytotoxicity of polyethylenimine, the nanoparticle Si26H, and their complexes with plasmid DNA. When applied in concentrations used for transfection, $\mathrm{pEI}$ and $\mathrm{pEI}$-DNA complexes reduced viability by up to $50 \%$, while no significant toxicity could be detected for Si $26 \mathrm{H}$ and its complexes with DNA. In the absence of serum, the factor between the $\mathrm{Si} 26 \mathrm{H}$ concentration required for optimum transfection and the $\mathrm{LD}_{50}$ of the corresponding complexes was approximately 25 . Addition of serum further reduced the cytotoxicity (Figure 2B).

AF M. Atomic force microscopy of Si26H-DNA complexes revealed a structure that can be described with the spaghetti-meatball model. Figure 3 shows a typical example at high resolution. The surface was dominated by $\mathrm{Si} 26 \mathrm{H}$ nanoparticles, while DNA strands were not visible and appeared to be localized in the interior. Although the DNA strands could not be resolved within the complex, it can be concluded from the absence of submicron aggregates in DNA-free samples that DNA is wound around and sandwiched by multiple nanoparticles to become physically condensed and covered by these. The size of the resulting complexes was found to be in the range between 100 and $200 \mathrm{~nm}$.

Correlation of Physicochemical Parameters. There was a strong correlation between the nanoparticle induced decrease in ethidium bromide intercalation, the electrophoretic immobilization of DNA and its removal from solution by centrifugation (Figure 5 ). All three parameters show significant binding of plasmid DNA at w/w ratios $\mathrm{Si} 26 \mathrm{H}$ :DNA above 1, reaching $50 \%$ at ratios between 4 and 5 . At ratios above $10,>90 \%$ of the plasmid was bound to the particle surface as determined by agarosegel electrophoresis (Figure 4). Cosedimentation analysis predicted only $80 \%$ binding at this ratio. Upon addition of more $\mathrm{Si} 26 \mathrm{H}$, the DNA binding reached $100 \%$. The exclusion of ethidium bromide from the complex, however, never exceeded $90 \%$.

$\mathrm{Si} 26 \mathrm{H}-\mathrm{pCMV} \beta$ complexes with w/w ratios of 10,30 , 100 , and 300 were analyzed for their surface charge by $\xi$
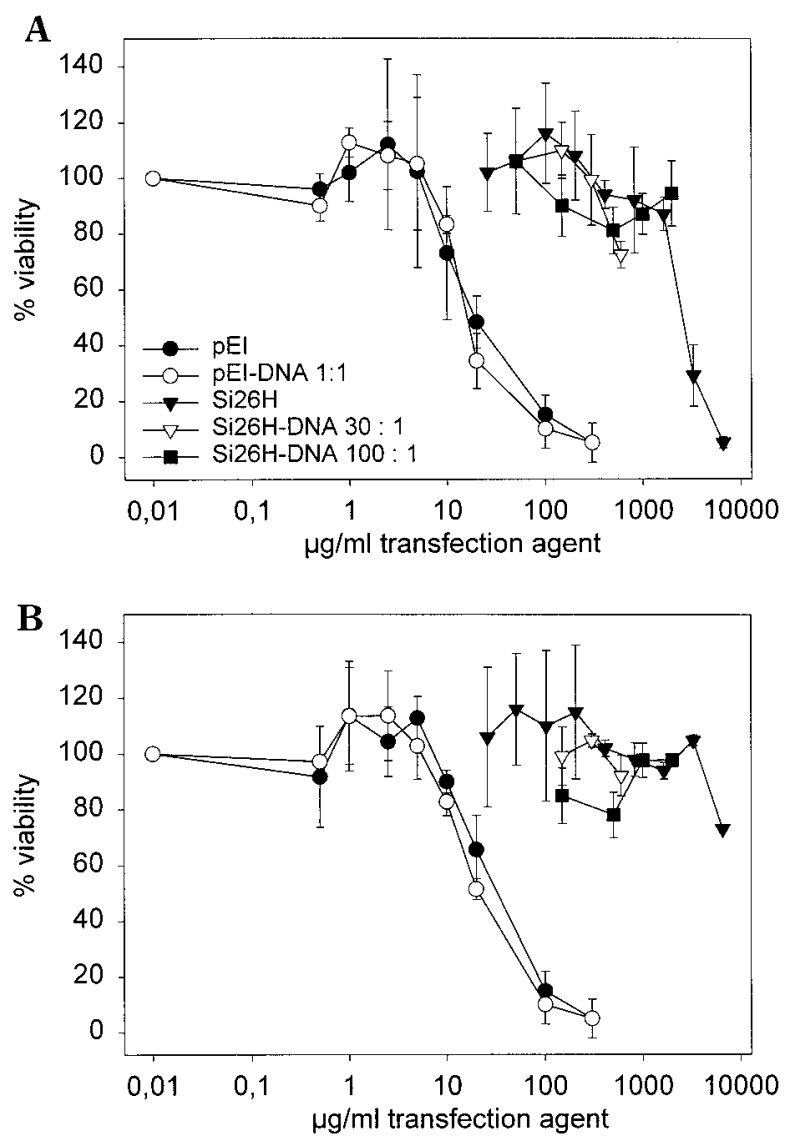

Figure 2. Comparative in vitro cytotoxicity of polyethylenimine and $\mathrm{Si} 26 \mathrm{H}$ and their complexes with DNA. Semiconfluent Cos-1 cells grown on 96-well plates were incubated for $4 \mathrm{~h}$ with increasing concentrations of $\mathrm{pEI}, \mathrm{Si} 26 \mathrm{H}$, or transfection complex in (A) DMEM or (B) DMEM + $10 \% \mathrm{fcs}$, supplied with fresh medium and assayed for viability (WST-1) after a further $48 \mathrm{~h}$ of growth in DMEM supplemented with $10 \% \mathrm{fcs}$. Concentrations always relate to $\mathrm{pEI}$ or $\mathrm{Si} 26 \mathrm{H}$.

potential measurement (Figure 5). Addition of 10 weight equivalents of $\mathrm{Si} 26 \mathrm{H}$ increased the $\zeta$ potential from approximately $-70 \mathrm{mV}$ for free plasmid DNA to $-34 \pm$ $5 \mathrm{mV}$. At a ratio of 30 , the complexes displayed a $\xi$ potential of $+25 \pm 5 \mathrm{mV}$, which did not increase further upon addition of more Si26H (28 $\pm 5 \mathrm{mV}$ at 100:1 and $24 \pm 5 \mathrm{mV}$ at 300:1)

To relate the $\mathrm{w} / \mathrm{w}$ ratio $\mathrm{Si} 26 \mathrm{H} / \mathrm{DNA}$ to the balance of positive and negative charges, the average content of the charge carriers nitrogen and phosphate per gram of $\mathrm{Si} 26 \mathrm{H}$ and plasmid DNA, respectively, was calculated. On the basis of the carbon analysis of the unmodified base particle (IPAST) and Si26H, the degree of modfication could be estimated for $\mathrm{Si} 26 \mathrm{H}$ as $0.00048 \mathrm{~mol}$ of nitrogen/g of particle dry weight (Table 1). The phosphate content of DNA can be calculated as $0.003 \mathrm{~mol}$ of phosphate/g of DNA, assuming an average molecular weight of $330 \mathrm{~g} / \mathrm{mol}$ of nucleotide. Hence, the w/w ratios $\mathrm{Si} 26 \mathrm{H} / \mathrm{DNA}$ of 1,10 , and 30 correspond to N/P ratios of $0.16,1.6$, and 4.8 , respectively (Table 3 ).

\section{DISCUSSION}

For the purpose of gene transfer, DNA has successfully been complexed with a range of materials including polycationic polymers and cationic liposomes or included in chitosan micro- and nanoparticles. Attempts have also been made to adsorb DNA onto the surface of colloidal particles. So far, dendrimers which are typically smaller than $10 \mathrm{~nm}$ and organic nanoparticles that are around 

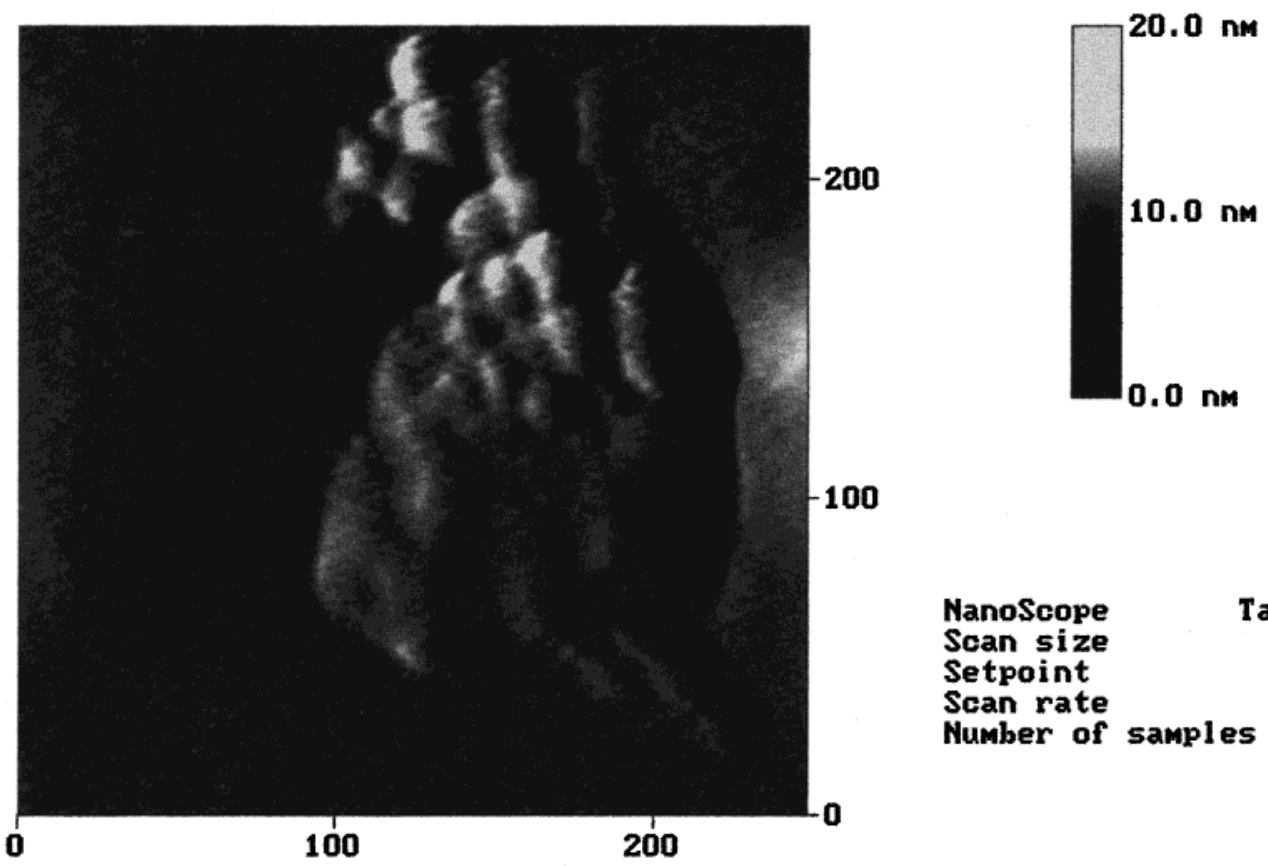
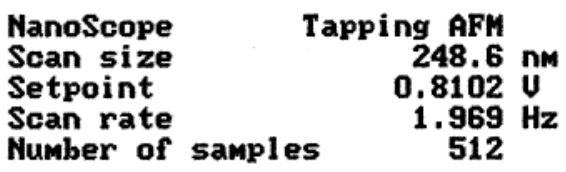

Figure 3. Atomic force microscopy of $\mathrm{Si} 26 \mathrm{H}-\mathrm{DNA}$ complexes. A suspension of Si26H was added to plasmid DNA to give final concentrations of $20 \mu \mathrm{g} / \mathrm{mL}$ DNA and $600 \mu \mathrm{g} / \mathrm{mL} \mathrm{Si} 26 \mathrm{H}$. The sample was applied to silicium wafers and allowed to adsorb for $30 \mathrm{~min}$ at room temperature. I maging was performed in tapping mode on a Nanoscope III a using a $\mathrm{Si}_{3} \mathrm{~N}_{4}$ cantilever with a spring constant of $34 \mathrm{~N} / \mathrm{m}$

w/w ratio Si26H: pCMVbeta

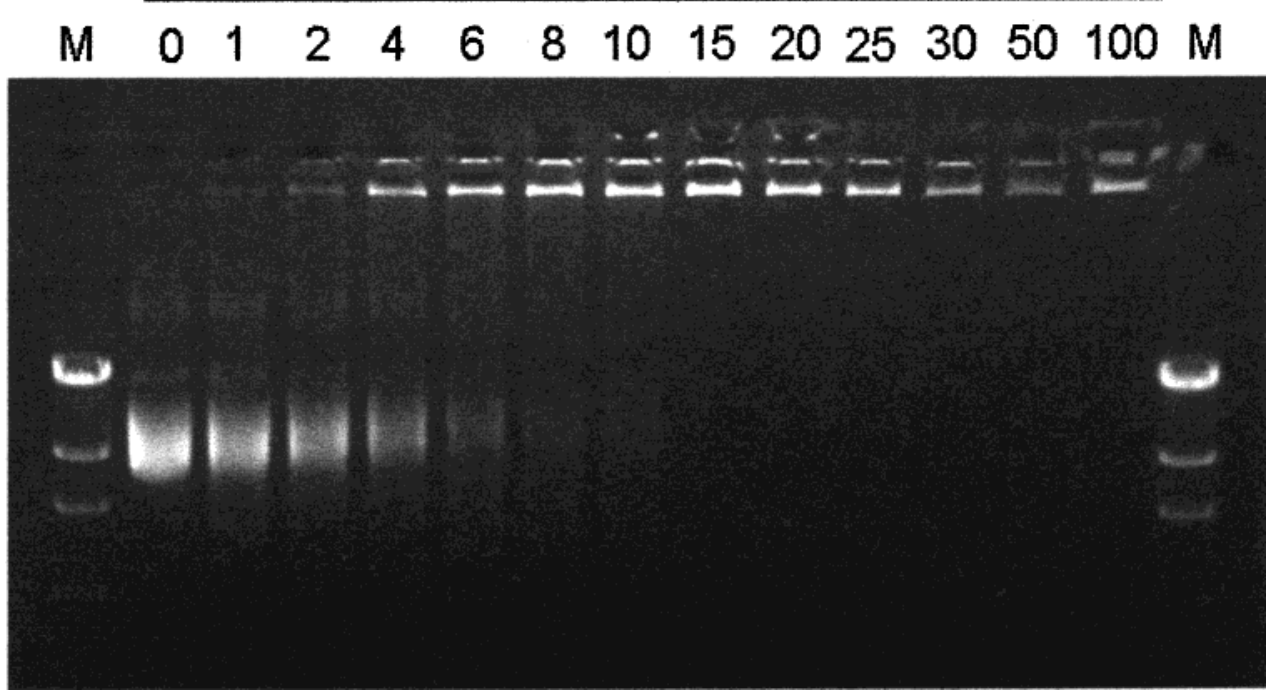

Figure 4. Agarosegel el ectrophoresis of Si26H-pDNA complexes. Lanes M show DNA marker IV, other lanes correspond to Si26H $\mathrm{pCMV} \beta$ complexes prepared at the w/w ratio given on top. The DNA was visualized by ethidium bromide staining and UV transillumination.

$300 \mathrm{~nm}$ have been evaluated $(3,25)$. We have synthesized cationically modified silica nanoparticles with sizes of $10-100 \mathrm{~nm}$, that can adsorb DNA, resulting in complexes typically between 100 and $300 \mathrm{~nm}$ that should be suitable for cellular uptake. It could now be demonstrated that these particles are also able to efficiently transfect plasmid DNA into cultured cells.

All of the three particle batches tested resulted in measurable and significant gal actosi dase activity, while DNA alone was inactive. The ratio of particle:DNA optimal for transfection correlated well with the DNAbinding behavior. As shown by agarosegel electrophoresis and cosedimentation analysis, 10 equiv of $\mathrm{Si} 26 \mathrm{H}$ were sufficient to bind $>90 \%$ of the plasmid DNA. The trans- fection efficiency in the absence of serum peaked at the same ratio. Interestingly, the resulting complexes still displayed a negative surface charge as shown by $\xi$ potential measurements. This confronts with the paradigm that either a high positive charge or specific cellular recognition is necessary for transfection. The addition of fetal calf serum further improved gene expression after transfection with these complexes. This effect was especially pronounced for $\mathrm{Si} 26 \mathrm{H}-\mathrm{DNA}$ complexes prepared at ratios above 10, which did also display a positive surface charge. This is surprising, as most polyplexes are either not or negatively affected by serum (26). On the underlying mechanism can only be speculated. Both a 


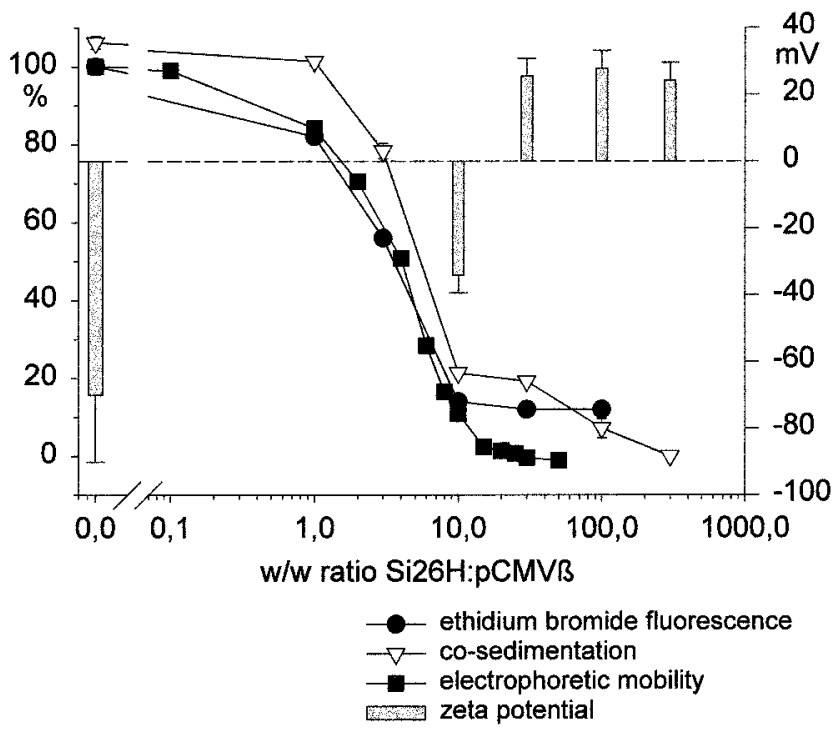

Figure 5. Physicochemical characterization of Si26H-DNA complex formation. Plasmid DNA was incubated with increasing amounts of Si26H at pH 7.4 in $50 \mathrm{mM}$ HEPES for $10 \mathrm{~min}$. Ethidium bromide exclusion from $\mathrm{Si} 26 \mathrm{H}-\mathrm{DNA}$ complexes, immobilization of DNA in the agarosegel by Si26H, removal of soluble DNA from solution by $\mathrm{Si} 26 \mathrm{H}$, and subsequent centrifugation and the $\zeta$ potential of the formed complexes were determined as described in Experimental Procedures.

Table 3. Conversion of w/w Ratios into N/P Ratios for Si26H-DNA Complexes

\begin{tabular}{cc}
\hline w/w ratio & N/P ratio \\
\hline 1 & 0.16 \\
3 & 0.48 \\
10 & 1.6 \\
30 & 4.8
\end{tabular}

a Assuming $0.00048 \mathrm{~mol}$ of $\mathrm{N} / \mathrm{g}$ of particle and average $300 \mathrm{~g} / \mathrm{mol}$ nucleotide.

physical stabilization or enhancement of cell binding by either specific or unspecific mechanisms would appear feasible

Another feature of all investigated NP-DNA complexes is that transfection was strongly enhanced by the presence of chloroquine in the transfection medium. As chloroquine is thought to act either via inducing endosomolysis or delaying the endosomal decomposition (8), this would suggest that the complexes are internalized by endocytosis and routed to the endosomal/lysosomal compartment. This is not surprising as this pathway is thought to be used by most polyplexes $(9,14,27,28)$. However, there is still no agreement on the mode of action of chloroquine, and induction of complex dissociation is discussed as an alternative mechanism to endosomolysis (29). Some of the polymers used for transfection, e.g., polyethyleneimine, possess an intrinsic endosomolytic activity, which has been associated with the buffering effect during endosomal acidification. Such polymers require higher nitrogen/phosphate (N/P) ratios of at least 6 for DNA complexation at neutral $\mathrm{pH}$ than nonendosomolytic polymers such as poly-L-lysine. Polylysine complexes are usually most effective in the presence of chloroquine and at N/P ratios between 2 and 4 (30). F or Si26H - DNA complexes, we cal culated a conversion factor w/w ratio to N/P ratio of 0.16 based on the carbon analysis of Si26H and an average molecular weight of $330 \mathrm{~g} / \mathrm{mol}$ nucleotide. This correlates well with the negative $\xi$ potential at $\mathrm{w} / \mathrm{w}=10(\mathrm{~N} / \mathrm{P}=1.6)$ when it is taken into account that the immobilized imino and amino groups are not fully protonated under these conditions. It would also suggest, that $\mathrm{Si} 26 \mathrm{H}$ should, in regard to endosomolysis, rather behave like polylysine than polyethyleneimine. Increasing the buffering capacity of these cationically modified silica nanoparticles might therefore represent a rational approach to improve their potential as transfection agent.

There are a few unique features that make the surfacemodified silica nanoparticles described here appear as a promising DNA carrier for transfection systems. Although there are concerns that $\mathrm{SiO}_{2}$ can exert adverse effects by the induction of $\mathrm{NF} \kappa \mathrm{B}$ (31), colloidal silica is biologically inert and showed much lower cytotoxicity than polyethylenimine. Silica is widely used in cosmetics and pharmaceuticals, for instance as highly disperse $\mathrm{SiO}_{2}$ (Aerosil) as an excipient for solid oral dosage forms. Furthermore, existing technol ogy could be applied to link ligand molecules via remaining functional groups onto the surface of SiNP-DNA complexes to mediate specific interactions. At least at a sufficient ratio SiN P:DNA, the complex surface is dominated by particle half-spheres, as shown by atomic force microscopy. It does not seem unreasonable to assume, that these half-spheres are not directly involved in DNA binding and carry functional groups that will allow further chemical modification without disturbing the structure of the complex. The facts that lyophilizing and autoclaving SiNP should, in principle, be possible, are further aspects that might make them an attractive addition to the existing repertoire of DNA vectors.

\section{ACKNOWLEDGMENT}

This work is part of the interdisciplinary research program "Biologically composed materials and systems" sponsored by the Department of Education, Culture and Science of the Saarland. We thank the "Fonds der Chemischen Industrie" for financial support. U.B. wishes to thank "Stiftung Deutscher Naturforscher Leopol dina" (BMBF/LPD-9901/8-6). Mrs. N. Zghoul is thanked for critical proof-reading of the manuscript.

\section{ABBREVIATIONS}

Abbreviations used: CQ, chloroquine; fcs, fetal calf serum; pEI, polyethylenimine; pLL, poly-L-Iysine; SiNP, silica nanoparticles; w/w, weight/weight ratio.

\section{LITERATURE CITED}

(1) Zelphati, O., Nguyen, C., Ferrari, M., Felgner, J ., Tsai, Y., and F elgner, P. L. (1998) Stable and monodisperse lipoplex formulations for gene delivery. Gene Ther. 5, 1272-1282.

(2) Boussif, O., Lezoualc'h, F., Zanta, M. A., Mergny, M. D., Scherman, D., Demeneix, B., and Behr, J. P. (1995) A versatile vector for gene and ol igonucleotide transfer into cells in culture and in vivo: Polyethylenimine. Proc. Natl. Acad. Sci. U.S.A. 92, 7297-7301.

(3) Haensler, J ., and Szoka, F. C., J r. (1993) Polyamidoamine Cascade Polymers Mediate Efficient transfection of Cells in Culture. Bioconjugate Chem. 4, 372-379.

(4) Gottschalk, S., Sparrow, J. T., Hauer, J., Mims, M. P., Leland, F. E., Woo, S. L. C., and Smith, L. C. (1996) A novel DNA-peptide complex for efficient gene transfer and expression in mammalian cells. Gene Ther. 3, 448-457.

(5) Blessing, T., Remy, J . S., and Behr, J . P. (1998) Monomolecular collapse of plasmid DNA into stable virus-like particles. Proc. Natl. Acad. Sci. U.S.A. 95, 1427-1431.

(6) Wagner, E., Zenke, M., Cotten, M., Beug, H., and Birnstiel, M. L. (1990) Transferrin-polycation conjugates as carriers for DNA uptake into cells. Proc. Natl. Acad. Sci. U.S.A. 87, 341014.

(7) Wagner, E., Plank, C., Zatloukal, K., Cotten, M., and Birnstiel, M. L. (1992) Influenza virus hemagglutinin HA-2 
$\mathrm{N}$-terminal fusiogenic peptides augment gene transfer by transferrin-polylysine-DNA complexes: toward a synthetic virus-like gene-transfer vehicle. Proc. Natl. Acad. Sci. U.S.A. 89, 7934-7938.

(8) Luthman, H., and Magusson G. (1983) High efficiency polyoma DNA transfection of chloroquine treated cells. Nucleic Acids Res. 11, 1295-1308.

(9) Wagner, E., Zatloukai, K., Cotten, M., Kirlappos, H., M echtler, K., Curiel, D. T., and Birnstiel, M. L. (1992) Coupling of adenovirus to transferrin-polylysin/DNA complexes greatly enhances receptor-mediated gene delivery and expression of transfected genes. Proc. Natl. Acad. Sci. U.S.A. 89, 60996103.

(10) Zanta, M. A., Belguise-Valladier, P., and Behr, J . P. (1999) Gene delivery: a single nuclear localization signal peptide is sufficient to carry DNA to the cell nucleus. Proc. Natl. Acad. Sci. U.S.A. 96, 91-96.

(11) Pouton, C. W. (1998) Nuclear import of polypeptides, polynucleotides and supramolecular complexes. Adv. Drug Delivery Rev. 34, 51-64.

(12) Mizuguchi, H., Nakagawa, T., Morioka, Y., Imazu, S., Nakanishi, M., Kondo, T., Hayakawa, T., and Mayumi, T. (1997) Cytoplasmic gene expression system enhances the efficiency of cationic liposome-mediated in vivo genetransfer into mouse brain. Biochem. Biophys. Res. Commun. 234, 1518.

(13) Pouton, C. W., and Seymour, L. W. (1998) Key issues in nonviral gene delivery. Adv. Drug Delivery Rev. 34, 3-20.

(14) Plank, C., Zauner, W., and Wagner, E. (1998) Application of membrane-active peptides for drug and gene delivery across cellular membranes. Adv. Drug Delivery Rev. 34, $21-$ 36.

(15) Mönkkönen, J., and Urtti, A. (1998) Lipid fusion in oligonucleotide and gene delivery with cationic lipids. Adv. Drug Delivery Rev. 34, 37-50.

(16) Cotten, M. (1994) Adenovirus-Augmented, Receptor-Mediated Gene Delivery and some Solutions to the Common Toxicity Problems. In The Molecular Repertoire of Adenoviruses III - Biology and Pathogenesis. Current Topics in Microbi ol ogy and I mmunol ogy 199 (W. Doerfler and P. Möhm, Eds.) pp 283-295, Springer-Verlag, Berlin.

(17) Kneuer, C., Sameti, M., Haltner, E. G., Schiestel, T., Schirra, H., Schmidt, H., and Lehr, C. M. (2000) Silica nanoparticles modified with aminosilanes as carriers for plasmid DNA. Int. J. Pharm. (In press).

(18) Cherng, J . Y., van de Wetering, P., Talsma, H., Crommelin, D. J . A., and Hennink, W. E. (1996) Effect of Size and serum Proteins on Transfection Efficiency of Poly((2-dimethylamino)ethyl Methacrylate)-Plasmid Nanoparticles. Pharm. Res. $13,1038-1042$.

(19) Godbey, W. T., Wu, K. K., Hirasaki, G. J ., and Mikos, A. G. (1999) I mproved packing of poly(ethylenimine)/DN A complexes increases transfection efficiency. GeneTher. 6, 13801388.
(20) Wu, Y. L., J iang, C., and Ku, K. Y. (1993) The effects of polylysine on the aggregation of surface and on the cleavage furrow of Rana amurensis eggs. Shih Yen Sheng Wu Hsueh Pao 16, 51-64.

(21) Yaroslavov, A. A., Kulkov, V. E., Polinsky, A. S., Baibakov, B. A., and Kabanov, V. A. (1994) A polycation causes migration of negatively charged phospholipids from the inner to outer leaflet of the liposomal membrane. FEBS Lett. 340, 121-123.

(22) Takahashi, H., Matuoka, S., Kato, S., Ohki, K., and Hatta, I. (1992) Effects of poly(L-lysine) on the structural and thermotropic properties of dipalmitoyl phosphatidylglycerol bilayers. Biochim. Biophys. Acta 1110, 29-36.

(23) Boussif, O., Delair, T., Brua, C., Veron, L., Pavirani, A. and Kolbe, H. V. (1999) Synthesis of polyallylamine derivatives and their use as gene transfer vectors in vitro. Bioconjugate Chem. 10, 877-883.

(24) Araki, T., Yamamoto, A., and Yamada, M. (1987) Accurate determination of DNA content in single cell nudei stained with Hoechst 33258 fluorochrome at high salt concentration. Histochemistry 87 (4), 331-338.

(25) Maruyama, A., Ishihara, T., Kim, J. S., Kim, S. W., and Akaike, T. (1997) Nanoparticle DNA Carrier with Poly(Llysine) Grafted Polysaccharide Copl olymer and Poly(D,L-lactic acid). Bioconjugate Chem. 8, 735-742.

(26) Dash, P. R., Read, M. L., Barrett, L. B., Wolfert, M. A., and Seymour, L. W. (1999) Factors affecting blood dearance and in vivo distribution of polyelectrolyte complexes for gene delivery. Gene Ther. 6, 643-650.

(27) Coonrod, A., Li, F. Q., and Horwitz, M. (1997) On the mechanism of DNA transfection: efficient gene transfer without viruses. Gene Ther. 4, 1313-1321.

(28) Wolfert, M. A., and Seymour, L. W. (1998) Chloroquine and amphipathic peptide helices show synergistic transfection in vitro. Gene Ther. 5, 409-414.

(29) Erbacher, P., Roche, A. C., Monsigny, M., and Midoux, P. (1996) Putative Role of Chloroquine in Gene Transfer into a Human Hepatoma Cell Line by DNA/Lactosylated Polylysine Complexes. Exp. Cell. Res. 225, 186-194.

(30) Tang, M. X., and Szoka, F. C. (1999) The influence of polymer structure on the interactions of cationic polymers with DNA and morphology of the resulting complexes. Gene Ther. 4, 823-832.

(31) Chen, F., Lu, Y., Kuhn, D. C., Maki, M., Shi, X., Sun, S. C., and Demers, L. M. (1997) Calpain Contributes to SilicaInduced $I_{\kappa} \mathrm{B}-\alpha$ Degradation and Nudear factor $-\kappa \mathrm{B}$ Activation. Arch. Biochem. Biophys. 342 (2), 383-388. 